\title{
The diachronic study of orientations: Mérida, a case study
}

\author{
A. César González-García ${ }^{1}$ and Lourdes Costa-Ferrer ${ }^{2}$ \\ ${ }^{1}$ Instituto de Astrofísica de Canarias \& Universidad de La Laguna, \\ Vía Láctea s.n. 38200 La Laguna, Tenerife, Spain \\ email: cglez@iac.es \\ ${ }^{2}$ Independent Scholar, Tenerife, Spain \\ email: 1.cosfer@gmail.com
}

\begin{abstract}
The study of orientations is a key ingredient in most archaeoastronomical research. Typically, a number of synchronistic monuments belonging to a given culture or cultural horizon are measured and studied in order to see if they share a similar orientation. If an astronomical orientation appears, we may apply other archaeoastronomical procedures to justify further conclusions.

On a few occasions we perform studies that compare, for a given site, monuments of different periods. At most two or three periods are usually compared to verify persistence or to check for evolution in customs of orientation. We argue here that it would also be interesting to study orientations from a diachronic point of view, in order to investigate the persistence/evolution of this particular conception of space through time.

Mérida (Extremadura, Spain) and the neighbouring areas present a rich and highly interesting monumental heritage spanning from the Neolithic to the present, with monuments belonging to several different periods and cultures.

In the present study we will review the orientation of the monuments in that area. We will present some conclusions on the evolution/persistence of customs of orientation and value the applicability of this method to other areas.
\end{abstract}

Keywords. orientation, comparative studies, methodology, Roman towns

\section{Introduction}

Most studies in archaeoastronomy are undertaken from a synchronous point of view. These studies deal with items from the archaeological record (usually architectural constructions) in a relatively restricted geographic area and a similar historical period that evidently share a common cultural context (see S̆prajc (2004) and Belmonte et al. (2009) as two recent examples in literate cultures). In a number of cases, diachronic studies are performed that include, for the sake of comparison, items from immediately previous or posterior epochs in order to study possible evolution or to confirm or disprove a possible interpretation (see, e.g., Criado \& García Quintela (2007) for a comparison of Celtic and Roman sites and of Roman and early Christian ones).

We can visualize the situation in three-dimensional space with two spatial coordinates (i.e. latitude and longitude) and one temporal dimension. The temporal dimension is usually disregarded or little used. We would like here to explore the possibility of extending the temporal dimension further within a rather more restricted geographic area.

The different cultural strata present at many sites bear witness to the various ideas and religions that crossed the area in question and left their mark in different ways. One of these ways, which archaeoastronomy can explore, is the orientation of ritual and cult buildings. Changes in material culture are often linked with social upheavals due perhaps 
to invasions or to the arrival of new peoples and/or ideas. Where these changes affected the ideological or religious sphere, they can be reflected in the orientation of ritual or cult buildings such as temples, shrines or tombs.

We propose here to investigate the possibilities of a diachronic approach extending over a long timescale in order to identify and understand the possible persistence of, evolution of, or radical changes in, the orientation customs in a particular area and to compare them with cultural changes both known or suspected historically or inferred from the material culture.

In order to apply this approach we need a long and clear archaeological sequence extending back to early times. We have chosen that of the area near the Spanish town of Mérida. Although Mérida was already urbanized in Roman times (see below) a number of archaeological finds have been made within the town limits dating from the Chalcolithic to the 1st millennium BC (Alba Calzado 1997, Jiménez \& Barrientos 1997, Jiménez Ávila \& Sánchez Barrero 2001). Within a few tens of kilometers of Mérida there are archaeological remains from all historical periods. In the following sections, these will be compared with one another and with the evidence from other areas.

\section{Mérida and orientations across time}

\subsection{Dolmens}

The dolmens and passage graves in the area are the first monuments where we can measure an orientation. These monuments began to be built in the later phases of the Neolithic in the area (4th millennium BC), although most of them continued to be used in later times (Prada Gallardo \& Cerrillo Cuenca 2003; Enríquez Navascues et al. 1992).

There are four dolmens in the immediate vicinity of Mérida. The dolmens of Lácara, Dehesa de la Muela and Magacela (see Fig. 1c) have been measured by Hoskin (2001); another dolmen has been identified in Carmonita in the vicinity of Mérida and measured $\left(A=134^{\circ}\right)$.

The orientation of these monuments is compared with nearby areas in Fig. 1. These data were also taken from Hoskin (2001). The Mérida dolmens are oriented towards the arc of sunrise, with a tendency toward negative declinations. This pattern is consistent with the orientation of dolmens in areas to the west and north of Mérida. This area, and particularly the Alentejo, has been considered to be the possible origin for local customs of orientation in megalithic constructions (González García \& Belmonte 2010). However, the dolmens found to the south-east of this region do not have an orientation pattern consistent with this, perhaps indicating that they evolved from a different tradition.

\subsection{Tholoi and idols}

The 3rd millennium BC is characterised by the use of the first metals in the Chalcolithic period. Although the south-east of the Iberian Peninsula has yielded the earliest dates for Chalcolithic settlements, the rapid adoption of metals is attested by the archaeology throughout the southern half of the Peninsula (Fernández Castro 1997). This period is characterised in the Mérida area, as in other sites in the south-west, by the proliferation of fortified settlements (Hurtado 2004) perhaps indicative of new social complexity (Hurtado 1999) that is also reflected in the necropolis (García Sanjuan 2006). Necropoleis are the most prominent cult areas identified to date. The necropoleis of this time are still megalithic with a proliferation of the tholos-type tomb. There are 4 tholoi in the area, with the one in La Pijotilla being the closest to Mérida (Hurtado 1999). Most of these tholoi were measured by Hoskin (2001)). Figs $1 g \& h$ show the orientations of these monuments together with the orientation of all the tholoi in the Peninsula. We find that 
the two groups are compatible with each other, and that the tholoi orientations in general are less constrained than those in the previous period.

The transition from the Chalcolithic to the Bronze Age has been dated from the end of the 3rd into the 2nd millennium BC (Fernández de Castro 1997). A characteristic of this period is the re-use of former megalithic monuments and the presence of a large number of anthropomorphic idols in the sepulchres (Hurtado 2008). Of particular relevance for the area under study are the so-called plaque-idols. These have a near-trapezoidal shape with engravings on one of the surfaces. The central portions (main body) of these engravings typically contain some particular patterns. A statistical study by Belmonte \& Hoskin (2002) of the number of marks in the patterns on more than 100 plaque-idols showed significant occurrences of the numbers 12.5 and 28 , which can be linked to the lunar month and the number of lunations in a tropical year. This result implies that both solar and lunar observations were important and should be taken into account in our attempts to explain the orientation of the tholoi and perhaps earlier monuments.

\subsection{Bronze Age}

The Bronze Age in the region of Mérida is generally dated from the end of the 3rd to the early 1st millennium BC (Pavón Soldevila 1992, Fernández de Castro 1997). After this, the influence of contacts with Phoenicians and Greek colonies and the Tartessian culture in the south of the Peninsula brought about the Orientalizing Period.

A characteristic element of the Bronze Age in this region is the presence of warrior stelae (Galán Domingo 1993). These are supposed to mark the place where a funerary tumulus would have been located. One of the surfaces of the stela was typically engraved with a schematic figure of a man, together with weapons and a chariot. Unfortunately, all the existing stelae have now been moved into museums and private collections and no orientation measurements can be performed. However, a group called diadem stelae (owing to the presence of arches with a number of divisions) are worthy of note. It would

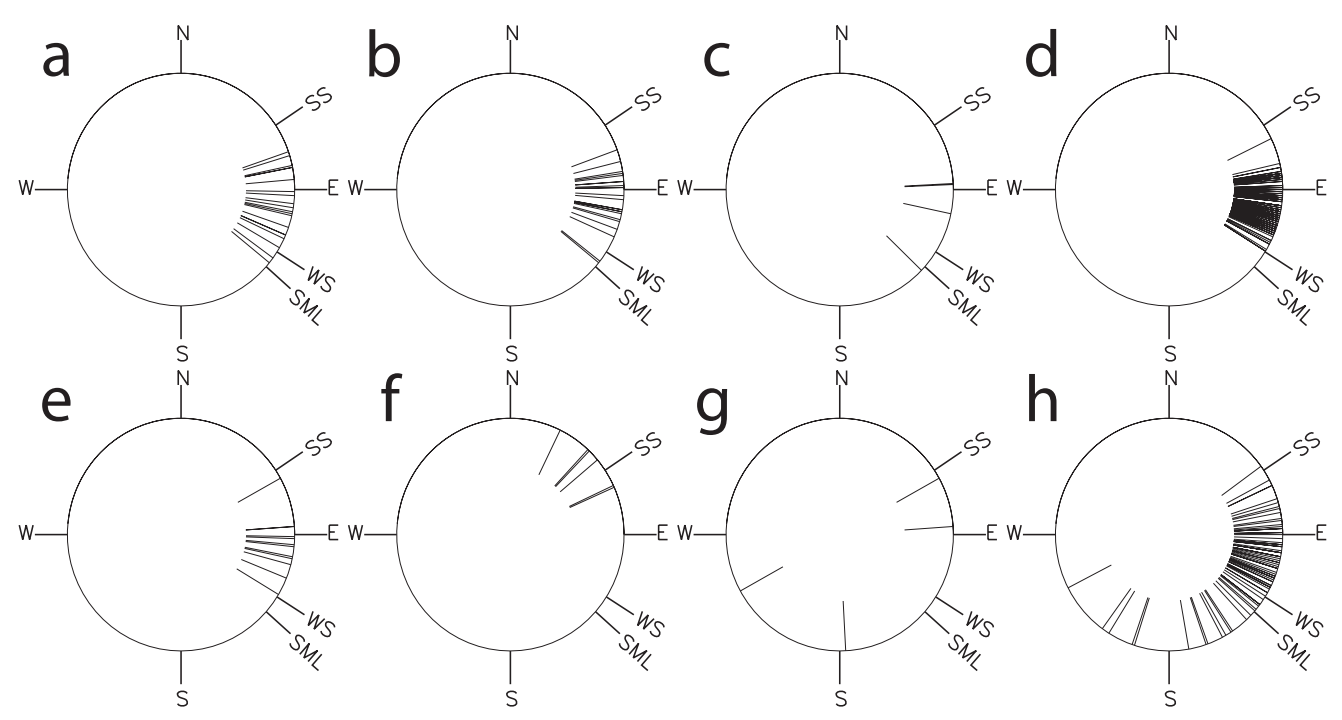

Figure 1. Orientation of dolmens and tholoi in the Mérida region compared to neighbouring areas. (a) dolmens in the area of Elbas (Portugal); (b) dolmens in the area of Caceres (Spain); $(c)$ dolmens near Mérida; $(d)$ dolmens in the Alentejo (Portugal); $(e)$ dolmens in the SW of Badajoz; $(f)$ dolmens in the SE of Badajoz; $(g)$ tholoi near Mérida; and $(h)$ tholoi in the Iberian Peninsula. 
be interesting to undertake a statistical study of the numbers typically found on these stelae in order to see if there is a change of custom in relation to the earlier plaque-idols.

Two orientalizing settlements have been identified in the vicinity of Mérida. One is in La Oliva de Mérida (Rovira Llorens 2005) and the second one in Medellín (AlmagroGorbea 2007). The necropolis of Medellín includes a number of tumular structures whose orientations are predominantly south-west to north-east (see Fig. $2 a$ ). Those orientations towards the north-east seem more likely to be lunar- than solar-related, although given the uncertain altitude of the horizon and the fact that the direction of the orientation of the tumuli cannot be determined, the target could also be solar.

Sites like Medellín are still present in the post-orientalizing period but the most characteristic monuments of this period are the so-called palace-sanctuaries, of which oneCancho Roano - is situated just a few kilometres from Mérida (see Celestino 2001 and Jiménez Ávila 1997). The layout of this monument is typical of Middle East temples and several stages of occupation have been identified. Our measurements, presented here, are broadly compatible with unpublished measurements taken by C. Esteban (priv. comm.), although we also include a measurement of the monument's entrance. This is skewed with respect to the main body of the building and points directly towards the ritual well in the courtyard. Such an orientation could (depending on the original horizon altitude) have aligned with summer solstice sunrise.

In Fig. $2 b$ we include orientations taken from the literature for palace-sanctuaries found in the area (Jiménez Ávila 2009). Despite the uncertainty in the map measurements, we can say that the orientations are exclusively towards the eastern half of the sky and all of them seem to be within the sun rising arc. This is different both from earlier and later orientatation patterns which appear more related to the solstices and/or lunistices.
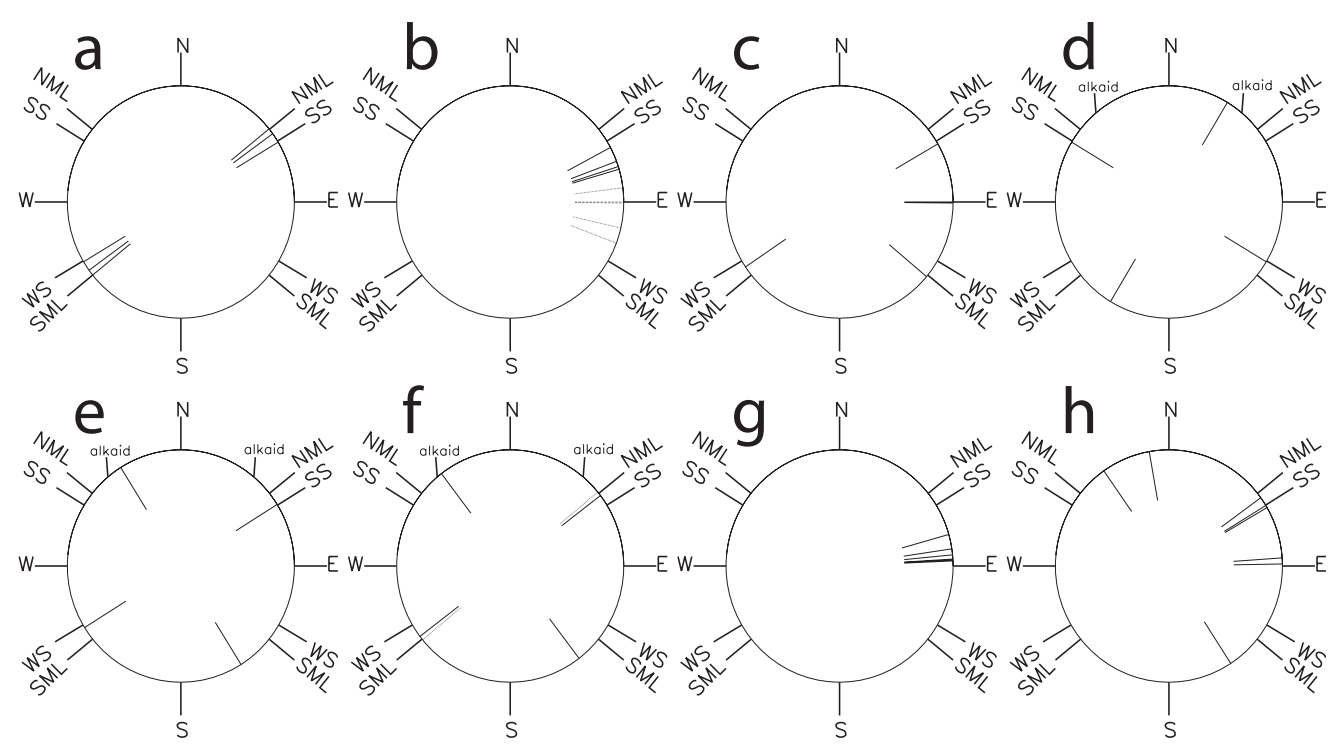

Figure 2. Orientation of cult structures from the Bronze Age to the Middle Ages. $(a)$ tombs from the Orientalizing Period settlement in Medellín; (b) palace-sanctuaries; $(c)$ Celtic tumuli and sanctuaries; $(d)$ the Roman town of Metellinum; $(e)$ the Roman town of Liberalitas Iulia; $(f)$ the Roman layout of Emerita Augusta (the Roman bridge is shown in a lighter linestyle); $(g)$ early Christian basilicas; and $(h)$ late medieval churches. 


\subsection{Iron Age}

In the second half of the 1st millennium BC up to the Roman conquest of the region, a number of different tribes are mentioned by the Classic sources (Strabo, Geography, Book III). The Mérida region, in particular, appears as a frontier area between several Celtic tribes to the north and west and certain Iberian or Turdetan ones to the south (Celestino Pérez et al. 1992, Pérez Macías 1996, Berrocal Rangel 1993). We have been able to measure a number of structures at two sites: Hornachuelos to the south of Mérida and Castrejon to the west. Hornachuelos has been identified as a Celtic site by the excavators. The structures in Hornachuelos are a number of funerary tumuli, both rectangular and round in shape (Rodríguez Díaz 1991). Castrejon is a Celtic oppidum (Berrocal Rangel 1993) where the excavators identified a peculiar room containing a great many pottery fragments and thus suspected it to be some kind of sanctuary. The structures at Hornachuelos and in Castrejon display curious possible associations with the extreme positions of the sun and/or moon (see Fig. 2c).

It should be noted here that in Roman times two main local deities are mentioned (among other deities less visible in the epigraphy). One is Endovellicus, whose main sanctuary was claimed to be at São Miguel da Mota in Portugal, near Mérida (Shattner et al. 2005). The other is Ataecina, identified with the Roman Proserpina, who appears in a large number of inscriptions, mostly from the area near Mérida and in particular from the Visigothic church of Santa Lucia del Trampal (Abascal Palazón 2002, Baraena 2005). Is any of them related to the sun or moon and would thus explain the peculiar orientations? Certainly much work is needed to answer these questions; this is out of the scope of this paper.

\subsection{Roman era}

The Roman presence in the area starts in the 2nd and 1st centuries BC. We have studied the orientation of Roman towns because the Classic sources describe in some detail the rituals and practices followed in the foundation of a new Roman town. According to Ovid, Plutarch and Vitruvius such rituals included the laying down of the pomerius, the sacred urban area, and the establishment of the mundus, the centre of the town where the two main streets, Cardus Maximus and Decumanus Maximus, met. According to Vitruvius, the directions of these streets was determined after observing the sun. It is still controversial whether such observations were actually performed and whether this could be discerned in present-day Roman remains (Magli 2008, Richardson 2005).

A Roman town was founded in Metellinum close to the previous Orientalizing Period settlement of Medellín (c. 79 BC; Haba Quiros 1998). This spot had strategic importance because there was a natural ford across the Guadiana river following the north-south transhumance route later called Vía de la Plata. Liberalitas Iulia was founded a few years later by Julius Caesar (59 BC; Marques de Farias 2001). The orientations of both towns are compatible with observations of the solstice sun (see Figs $2 d \& e$ ).

According to Cassius Dio, the foundation of Augusta Emerita took place after the campaign to conquest the north, and it has usually been dated at 25 BC (Roldan Hervas 2001). It has been traditionally accepted that the location and orientation of Mérida was determined by the Roman bridge. However, we detected a small but noticeable difference of almost three degrees between the orientation of the bridge and the Roman grid. Recently, archaeological excavations have uncovered evidence that there was a previous, demonstrably wooden, bridge on the site (Mateos Cruz 2001). In any case the orientation is not compatible with solar observations, and although it could perhaps be connected with the moon, this is highly debatable. Another possibility is that stars were used to 
determine north. The most westerly azimuth reached by the circumpolar star Alkaid is broadly compatible with the orientation of the Cardus Maximus (see Fig. $2 f$ ).

\subsection{Christian basilicas and Muslim mosque}

The next big change in the area occurs with the introduction of Christianity in the Later Roman Empire and Visigothic Kingdom. We have measured a number of Early Christian basilicas and churches. None of them follows the Roman grid; instead there is a clear preference towards orienting the apse or the altar to the east (see Fig. $2 g$ ). Historical surces indicate that such orientation was mandatory (see, e.g., McCluskey 1998).

In 713 Mérida was conquered by the Muslims and in 835 Abdalraman II built a fortress, the Alcazaba, next to the Roman bridge. Although it is certain that there were other mosques in Mérida, the only one identified to date is inside this fortress on top of the water reservoir, which is possibly of Roman origin. The orientation of this building is compatible with the orientation of most of the mosques in Al-Andalus, and also with the Roman grid, although does not provide an orientation towards Mecca.

Finally, we have measured a number of medieval Christian churches dating from after the Christian conquest of Mérida in 1230. Most of their orientations follow a two-fold pattern. Many of them face east, while others follow the Roman grid (see Fig. $2 h$ ).

\section{Discussion and conclusions}

We can summarise the orientations in all periods as follows. The dolmens could be related to the rising of either the sun or the moon (Hoskin 2001, da Silva 2004, González García \& Belmonte 2010) while the tholoi seems to lose this specificity, some being oriented towards the south and west as well. A change takes place in the Bronze Age, with the Orientalizing Period necropoleis showing for the first time in this area a preference toward the extreme solar and/or lunar positions. The later palace-sanctuaries do not

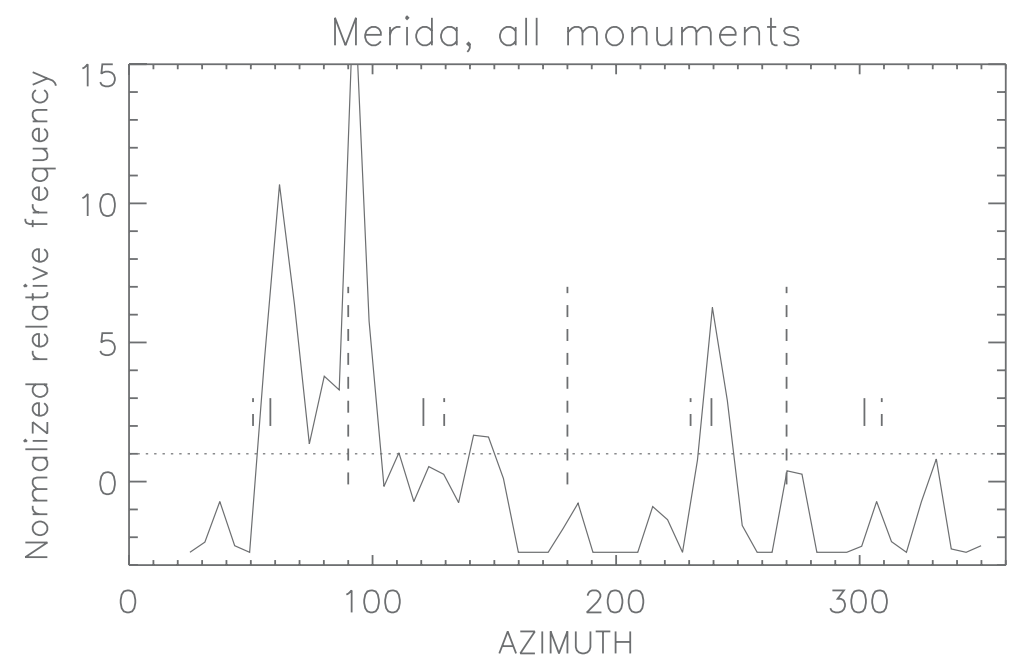

Figure 3. Histogram for the azimuth of all (54) structures measured near Mérida for all times considered. Although we are mixing monuments from different periods, this plot is illustrative of the predominant trends in orientation through history in Mérida. All periods are almost equally represented in number and thus the trend seems robust. Most monuments tend to be oriented towards the eastern half of the sky, most particularly to the east and to summer solstice sunrise. The latter group is related to the prominent group facing winter solstice sunset, since the directionality of many orientations is unknown. 
follow this new pattern but seem to follow a sun-rising custom (however, we note the possibly solstitial orientation of the well-entrance at Cancho Roano). The Iron Age seems to bring a more defined extreme-rising orientation pattern again. It is interesting that the newly founded Roman towns seem to have been orientated according to this local pre-existing pattern. Once the Roman grid is laid down the only monuments to break it are the Christian churches, although most of present day streets still follow that grid.

In short, we see that there is an overall evolution from broad, rising customs - perhaps related to lunar risings at particular moments in the year in the middle of the solar runto a specific interest in the extreme positions of the sun and/or moon. This might have been consolidated by the Roman grid of Mérida, and thereafter this orientation custom is only broken by the Christian churches. Overall, the large majority of monuments in this area are built with an interest in the eastern part of the horizon rather than the western part (see Fig. 3).

The orientation patterns tend to follow the cultural changes evident from the material and historical record, although there are notable exceptions. Some of the results need further study - such as the case of the diadem warrior stelae and the orientation of Iron Age structures-but it is clear that the orientation of Roman towns is of paramount importance. There seems to be a common pattern among the three Roman towns investigated in the area, although the data set is too small for us to be sure whether this pattern is real and, if so, whether it is related to astronomical and cult (perhaps local) practices or to more prosaic and practical issues as the need to avoid predominant winds (as advised by Vitrubius). A wider study of the orientation of Roman towns in Hispania is clearly central to addressing such questions. A large number of Roman towns were founded in the Peninsula over a relatively short period (see, e.g., Abad Casal et al. 2006), which provides a homogeneous data set well suited to be studied using proven archaeoastronomical methods.

Finally, the general approach is of wider applicability and validity. For example, it would be interesting to apply a similar methodology in an area such as the Andes, in places where there is a long record of different cultures from the formative period through to Inca times.

\section{Acknowledgements}

A.C. González-García is a Ramón y Cajal fellow of the Spanish Ministerio de Ciencia e Innovación (MICINN).

\section{References}

Abad Casal, L., Keay, S., \& Ramallo Asensio, S. 2006, Early Roman Towns in Hispania Tarraconensis, Journal of Roman Archaeology (Suppl. Series 62), Portsmouth RI.

Abascal Palazón, J. M. 2002, in L. Raposo (ed.), Religiões da Lusitânia, Museu Nacional de Arqueologia, Lisbon, pp. 53-60.

Alba Calzado, M. 1997, Memoria 1. Excavaciones Arqueológicas en Mérida, 1994-95, pp. 285319.

Almagro Gorbea, M 2007, La Necropolis de Medellín, Real Academia de la Historia, Madrid.

Baraena, M. L. 2005, Acta Paleohispanica IX, 5, 709-720.

Belmonte, J. A. \& Hoskin, M., 2002 Reflejos del Cosmos, Equipo Sirius, Madrid.

Belmonte, J. A., Shaltout, M., \& Fekri M. 2009, in J.A. Belmonte \& M. Shaltout (eds.), In Search of Cosmic Order: Selected Essays on Egyptian Archaeoastronomy, Supreme Council of Antiquities, Cairo, pp. 213-284.

Berrocal Rangel, L. 1993, Complutum 2/3 (Extra 2), 167-204 \& 205-242. 
Celestino, S. 2001, in D. Ruiz Mata \& S. Celestino (ed.), Arquitectura Oriental y Orientalizante en la Peninsula Ibérica, Madrid, 17-56.

Celestino Pérez, S., Enríquez Navascues, J. J. \& Rodríguez Díaz, A. 1992, Complutum, 2-3, 311-327.

Criado, F. \& García-Quintela, M. V. 2007, in M. P. Zedda \& J. A. Belmonte (eds.), Light and Shadows in Cultural Astronomy. Proceedings of SEAC 2005, Isili, Sardinia, Isili, pp. 87-99.

da Silva, M. 2004, Journal for the History of Astronomy, 35, 475-478.

Enríquez Navascues, J. J., Jiménez Alvárez, J., \& Haya Ignacio, A. 1991-1992, Norba. Revista de Historia, 11-12, 11-26.

Fernández de Castro, M. C. 1997, La Prehistoria de la Península Ibérica, Crítica, Barcelona.

Galán Domingo, E. 1993, Complutum, Extra 3.

García Sanjuán, L. 2006, in P. Díaz-del-Río \& L. García Sanjuán (eds), Social Inequality in Iberian Late Prehistory, BAR International Series 1525, Archaeopress, Oxford, pp. 149169.

González-García, A. C. \& Belmonte, J. A. 2010, Journal for the History of Astronomy, 41, $225-238$.

Haba Quiros, S. 1998, Medellín Romano, La Colonia Medellinensis y su Territorio, Diputación de Badajoz, Badajoz.

Hoskin, M. 2001, Tombs, Temples and their Orientations, Ocarina, Bognor Regis.

Hurtado Pérez, V. 1999, SPAL: Revista de Prehistoria y Arqueología de la Universidad de Sevilla, $8,47-83$.

Hurtado, V. 2004, Trabajos de Prehistoria, 61, 141-155.

Hurtado, V. 2008, in C. Cacho Quesada, R. Macías Ramos, J.A. Martos \& M.I. Martínez Navarrete (eds), Acercándonos al Pasado. Prehistoria en 4 Actos, Museo Arqueológico Nacional, Madrid.

Jiménez, J. \& Barrientos, T. 1997, Memoria 1. Excavaciones Arqueologicas en Mérida, 1994-95, p. 228.

Jiménez Ávila, J. 1997, Complutum, 8, 141-159.

Jimenez Ávila, J. 2009, Archivo Español de Arqueología, 82, 69-95.

Jiménez Ávila, J \& Sánchez Barrero, P. D. 2001, Memoria 5. Excavaciones Arqueológicas en Mérida, 1994-95, pp. 329-354.

Magli, G. 2008, Oxford Journal of Archaeology, 27, 63-71.

Marques de Faria, A. 2001, Pax Iulia, Felicitas Iulia, Liberalitas Iulia. Revista Portuguesa de Arqueologia 4(2), 351-362.

Mateos Cruz, P. 2001, Archivo Español de Arqueología, 74, 183-208.

McCluskey, S. C. 1998, Astronomies and Cultures in Early Medieval Europe, Cambridge University Press, Cambridge.

Pavón Soldevila, I. 1992, Norba. Revista de Historia, 11-12, 75-98.

Pérez Macías, J. A. 1996, SPAL: Revista de Prehistoria y Arqueología de la Universidad de Sevilla, 5, 101-114.

Prada Gallardo, A. \& Cerrillo Cuenca, E. 1996-2003, Norba. Revista de Historia, 16, 47-74.

Richardson, A. 2005, Oxford Journal of Archaeology, 24, 415-426.

Roldan Hervas, J. M. 2001, Militaria. Revista de Cultura Militar, 15, 19-38.

Rodríguez Díaz, A. 1991, Extremadura Arqueológica, 2, 283-300.

Rovira Llorens, S., Montero Ruiz, I., Ortega, J. \& Jiménez Ávila, J. 2005, in F. J. Jiménez Ávila \& S. Celestino Pérez (eds), El Período Orientalizante: Acts del III Simposio Internacional de Arqueología de Mérida 2, 1231-1240.

Schattner, T. G., Guerra, A. \& Fabião, C. 2005, Acta Paleohispánica IX, 5, 893-908.

S̆prajc, I. 2004, in J. B. M. Boccas, J. Broda \& G. Pereira (eds), Etno y Arqueo-Astronomía en las Américas. Memorias del Simposio ARQ-13: Etno y Arqueoastronomía en las Américas, 51 Congreso Internacional de Americanistas, Santiago de Chile, pp. 161-176. 